IBIMA Publishing

Journal of e-Government Studies and Best Practices

https://ibimapublishing.com/articles/JEGSBP/2020/608643/

Vol. 2020 (2020), Article ID 608643, 12 pages, ISSN: 2155-4137

DOI: $10.5171 / 2020.608643$

Research Article

\title{
E-Government in Romania - a Case Study
}

\author{
Marian STOICA and Bogdan GHILIC-MICU \\ Department of Economic Informatics and Cybernetics, Bucharest University of \\ Economic Studies, Bucharest, Romania
}

Correspondence should be addressed to: Marian STOICA; marians@ase.ro

Received date:13 November 2019; Accepted date:28 January 2020; published date: 18 June2020

Academic Editor: Georgeta Soava

Copyright (C) 2020. Marian STOICA and Bogdan GHILIC-MICU. Distributed under Creative Commons Attribution 4.0 International CC-BY 4.0

\begin{abstract}
Continuous development of digital communication systems has led to restructuring the information systems into ever cheaper, interconnectable and globally accessible entities, thus allowing individuals to turn towards the so-called e-Government (or electronic government). The government is an institution that fulfills critical needs of society; at some point every citizen has to interact with it. This paper reviews the general picture of the e-Government, with focuses on specific strategies and features of the Romanian electronic government approach, while proposing suggestions and solutions for developing each of them. Electronic government involves the adoption of information and communications technology (ICT) into government functions and procedures, with the goal of increasing efficiency, transparency and participation of citizens in the public life. Therefore, in order for a society to function well, a well-oiled electronic government is necessary. Electronic government uses ICT as a support tool for developing a good government. Proper application of e-Government allows increasing efficiency for governing tasks, improving processes and procedures, increasing quality of public services, improving the use of information in decision making processes and improving communication between various government entities. Through electronic government, municipalities have direct interaction with the citizens. The relation between municipalities and citizens is unavoidable, in terms of; commercial records of corporations, registrations of motor vehicles or enlisting a child into a school,all these require the citizens to interact with state authorities. The goal of e-government is to create a new dynamic relation between governments and citizens; a cycle that will become simpler and more inclusive for them.
\end{abstract}

Keywords: E-Government, ICT, Interoperability, Efficiency, Trust.

Cite this Article as: Marian STOICA and Bogdan GHILIC-MICU (2020)," E-Government in Romania - a Case Study", Journal of e-Government Studies and Best Practices, Vol. 2020 (2020), Article ID 608643, DOI: $10.5171 / 2020.608643$ 


\section{Introduction}

The technological advancements of the last decades have led to an explosion of information systems related to data administration and providing services for more efficient activities. This has led to an immediate evolution of both individual interactions between individuals and between individuals and various economic, social or administrative entities. While the private side has seen a more rapid evolution, the public side is slower, but with some mentionable achievements. With this background, the electronic government may be seen as a reform of the entire administrative system of a state, which implies modernizing the processes through modern technologies provided by the current informational systems. The need for such reform is invoked by the need to streamline some bureaucratic processes and/or entirely eliminate others. Thus, electronic government represents the entirety of actions performed by the state through electronic systems, like storing information about citizens, tax and fee payments, announcements for the population, public procurement, etc.

In order to define electronic government, the literature proposes plenty meanings and significances associated with the main characteristics of the phenomenon. For example, in the view of the World Bank from Worldbank Report (2018), electronic government means government agencies using informational technologies that have the ability to transform the relations with citizens, organizations and other government agencies. These technologies may serve for a better provision of government services to citizens, an improvement of interactions with the business environment empowering the citizens through access to information or a better management of the government itself. According to Ana A. (2018), the potential benefits are; less corruption, improved transparency, improved convenience, increase of income and/or decrease of spending. To summarize the general idea, the e-government means using information and communications technologies (ICT) for improving the government procedures for the benefit of citizens, organizations and government itself.

The aim of electronic government is to innovate in the government activity through digitizing a large part of the information processed and through providing electronic services for the citizens. Thus, such government seeks to streamline the state activities and involve the population in the smooth running of things more actively. Governments must take the technological advances into account and move to modernize state institutions in the context of digital ecosystem of the present time.

Even if some institutions have an efficient activity, most of them stumble in the bureaucratic process, with insignificant achievements. According to Dumitrache A. (2019), electronic government is necessary because many processes of state activity are outdated and cumbersome, generating problems for both civil servants and citizens. Also, a streamlined activity of the state is in everybody's interest. Modernization and streamlining can be achieved through ICT, and the use of internet and modern hardware will positively influence the state activity.

\section{Electronic government - paradigm, content and functioning}

Electronic government is the process of recreating the public sector through digitization and new information management techniques. The final goal of this process is to increase the political participation of citizens and streamlining the administrative apparatus. According to Ghilic-Micu, B. (2002) and Ghilic-Micu, B. and Stoica, M. (2002), this approach reunites three basic models of egovernment; technical, managerial and functional paradigms. The technical paradigm means technological improvements and digitization. It can bring a series of improvements like; use of electronic mail for communication, use of web sites for dissemination of public information and use of information systems 
to manage the workflow documents. The technical paradigm is the most important one for electronic government because it is hard to bring improvements when the technology does not allow evolution. The managerial paradigm involves the adoption of new information management methodologies that improve employee productivity and streamline their activity. The functional paradigm means involving the citizens in political activities leading to increased efficiency of administrative apparatus and rapprochement between the state and the citizens.

For every state, a general governance process involves three entities; public administration, business environment and the citizens. For example, in Romania, the public administration includes all public institutions (with related agencies and subsidiaries) on a central and local level, plus some non-governmental organizations (in May 2017, there were 88000 registered NGOs in Romania). The business environment includes all commercial entities, associations, non-profit organizations and registered sole traders. The implementation of electronic government solutions must take into account the interactions involving the state. These interactions define the four dimensions of electronic government; in a decreasing order of importance, they are: relations between government and citizens (G2C - Government-to-Citizens), relations between government and business environment (G2B - Government-tobusiness), relations between government agencies (G2G - Government-toGovernment) and the relation between government employees (G2E Government-to-Employees). The G2C dimension is the most important because any government decision must take citizens into account.

All citizens and all European companies desire an easier access to public information, with better use of internet as one possible solution. Online public information makes internet more relevant to daily activities and can explosively increase the number of users, leading to the prevalence of participation in the informational society. The internet potential may be channeled, for example, for achieving the objectives of Amsterdam treaty (regarding the extension of European Parliament powers, October 1997, in effect since may $\left.1^{\text {st }}, 1999\right)$, for ensuring total transparency for citizens of activities and decisions of European Union institutions and for correct understanding of these decisions.

There is still more to be done, both by member states and European institutions to ensure citizens' access to online government information. Best solutions are those designed for use of non-specialists and which allow access to a large set of EGovernment administrative and juridical information (October 2019). Additional effort is required to make government sites easy to use for finding information, interacting with government services, and at the same time, observing data confidentiality standards.

Lack of fast access to key information in statistical and business fields affects the industries and inhibits the development of private services. These services have been one of the characteristics of the success of public information system of USA, for example. The goal of this action was to expand and simplify the access to the internet to make the public information system easier to access, thus stimulate the development of new private services, based on the newly available data sources. The potential benefits of this action are huge and include:

- Bringing government services closer to the citizen,

- $\quad$ Reducing government spending by cutting down bureaucracy,

- Creating new employment opportunities for service providers,

- Creating a better European information market.

In this context and according to EGuvernare (2019), the objectives of streamlining the public information system include the following: 
- $\quad$ Ensuring fast and easy access to at least four types of essential data: administrative and legislative information; cultural and environmental information; real time traffic information and gridlock information.

- Extensive use of internet to consult the population about important political decisions, by moving from a simple publication of information in the network to establishing forums for reactions and discussions, possibly with independent moderators.

- Ensuring bidirectional access of citizens to documents used in current activities (tax forms, financing applications etc.) which will allow them to receive information and send answers.

For this goal, at least in Europe, it is necessary to take ample consultations with member states to establish the current situation regarding access to information about the public sector and electronic interactions with citizens. The consultation should take into account the development of a frame for evaluating the progress regarding the access, through quantifiable qualitative criteria. Better access is demonstrated by the creation of an external correspondence registry, accessible through internet. Public authorities must reconsider their online strategy, build on existing results and best practices and develop more efficient approaches closer to the citizen.

\section{Work Frame for Electronic Government - Fiscal Dimension}

Beside the informative dimension that any electronic government must include, the state must implement solutions for the fiscal dimension; payment of taxes, and fees and fines. From this perspective, it must be easy for the citizen to pay any debt towards the state in a facile manner without waiting in queues. In order to solve the payment problem, the idea is to create a unique portal for all state institutions, usable to pay any type of debt toward the state, no matter if it is about a physical person or a juridical person. Also, this solution must be easy to use without extra trips for the citizen. The solution must also allow modern payment solutions, using credit cards and bank transfers.

The case study proposed as a solution for the fiscal dimension of electronic government includes two platforms that work in Romania: ghiseul.ro and anaf.ro. These solutions cover all aspects of the fiscal component in the relations between the Romanian state and its citizens and also between the state and the business environment.

Ghiseul.ro is dedicated to physical persons (including registered sole traders) and allows online payment of taxes and fees, towards both local authorities and national fiscal administration (figure 1). In an official acceptance, the platform is called SNEP Sistemul Național Electronic de Plată Online cu Cardul Bancar (National Electronic System for Online Payment with Banking Cards) and is the propriety of the Romanian Government, through the Ministry of Communications and Information Society. SNEP is meant to be used for finding information about debts (payment obligations) and paying them with banking cards, whether they are due towards local budgets, central budgets or other institutions, and also for paying various taxes and fees established by institutions. The payment is made online, using a banking card, with or without authentication.

The SNEP system is accessible only through authentication based on user name and password. After authentication, it allows the consultation to find due payment obligations towards enrolled institutions and to pay them online using Visa, Visa Electron, MasterCard and Maestro cards issued by any bank. 


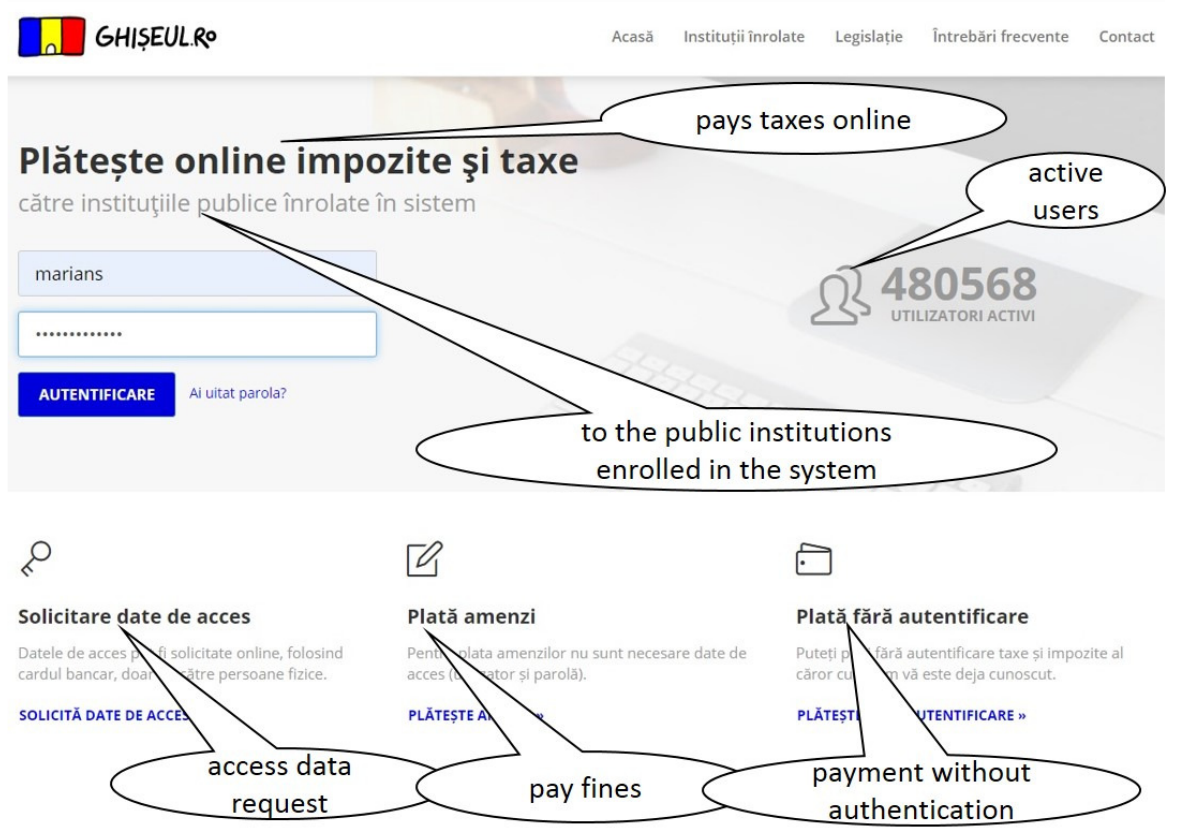

Fig. 1: Main page of ghiseul.ro portal

If the user does not already have an access account (user name and password) issued by the local authorities of his place of residence, he/she can create such an account in the main menu, following Access data request option (figure 1 ). To see a list of all the institutions that are enrolled in the system and active in a given county, click the county on the map; and on the right side of the map, the user will see the county name and a list of corresponding active institutions.

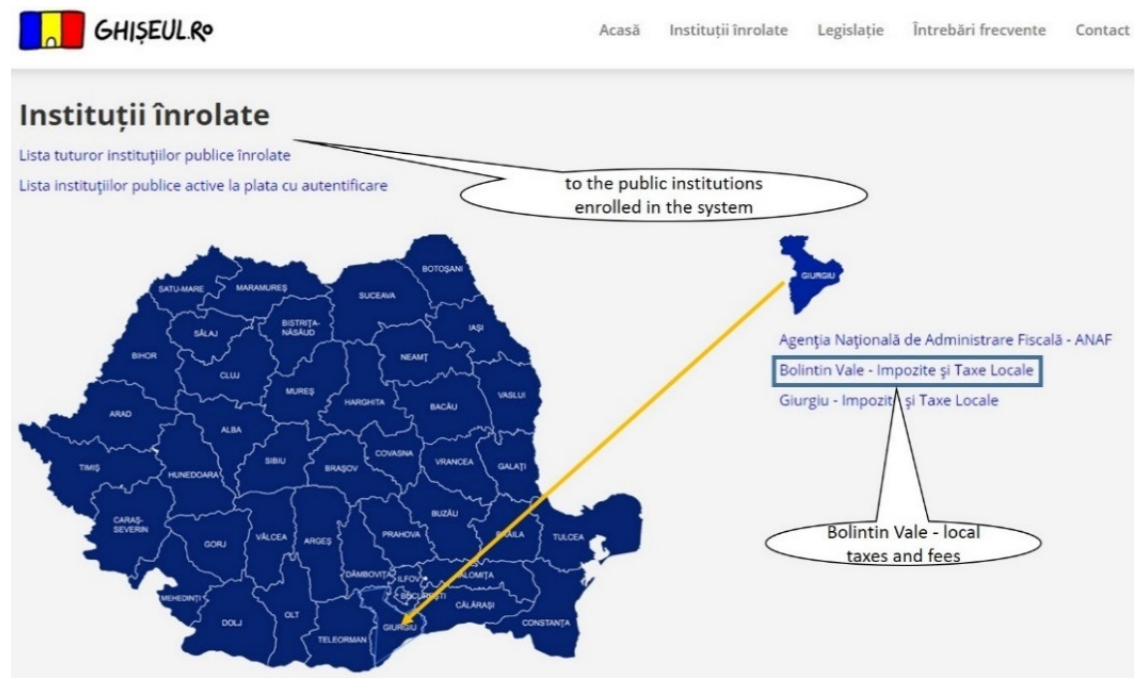

Fig. 2: Public institutions enrolled in SNEP

After authentication, the user will be able to access the section Obligații de plată (Payment obligations) (figure 3). In this section, the user can make payments covering various taxes. All due taxes are listed. 


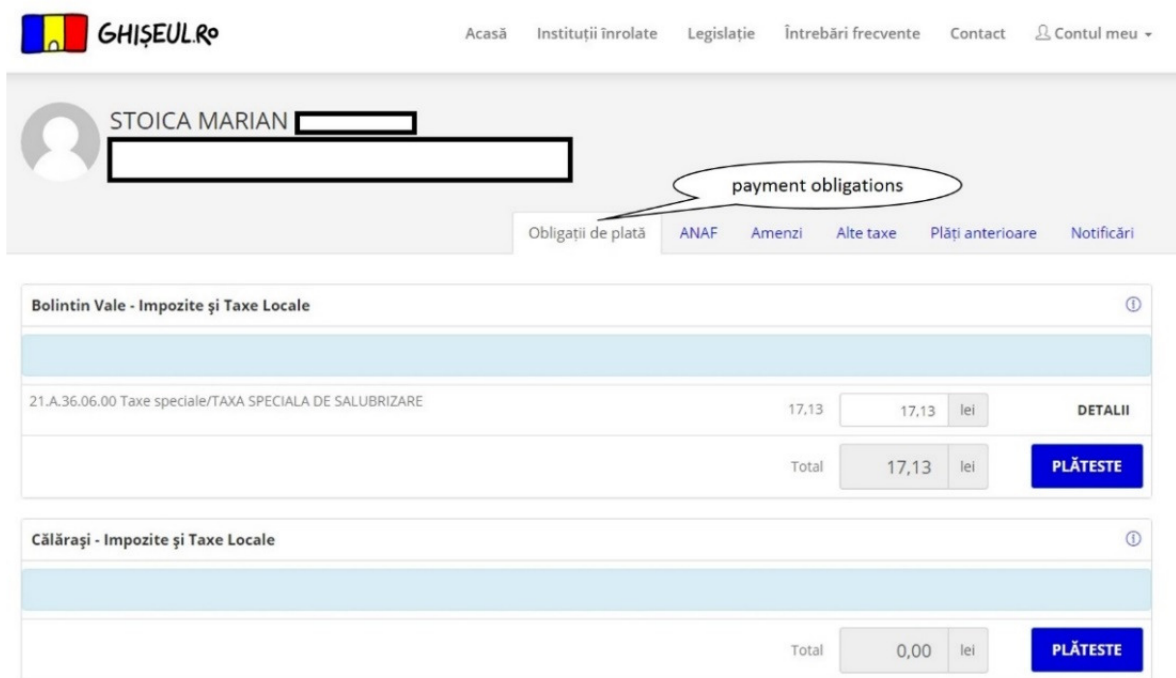

Fig. 3: Payment obligations section in SNEP

In this example, one of the authors finds out that there is a 17.13 lei special sanitation fee due towards the town hall of Bolintin Vale (place of residence). To prove the advantages of this e-government solution, this debt will be paid online, using a banking card. First, the payment will be previewed and then confirmed (figure 4).

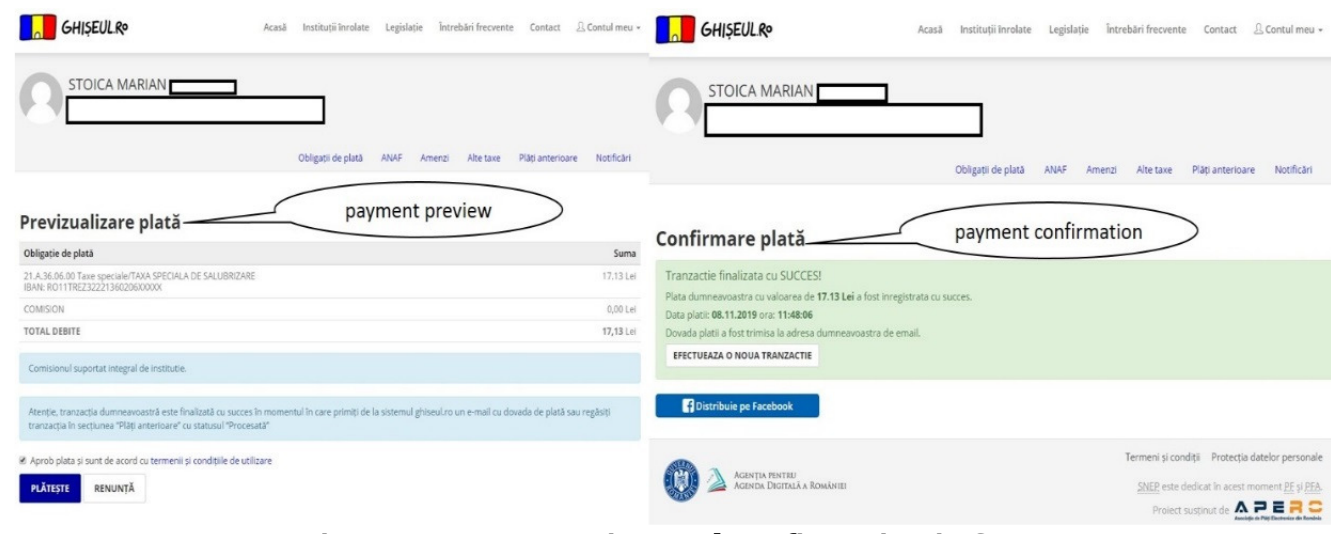

Fig. 4: Payment preview and confirmation in SNEP

After confirming the payment, it will show up in payment history with status $\hat{I} n$ procesare (Processing) (figure 5). 


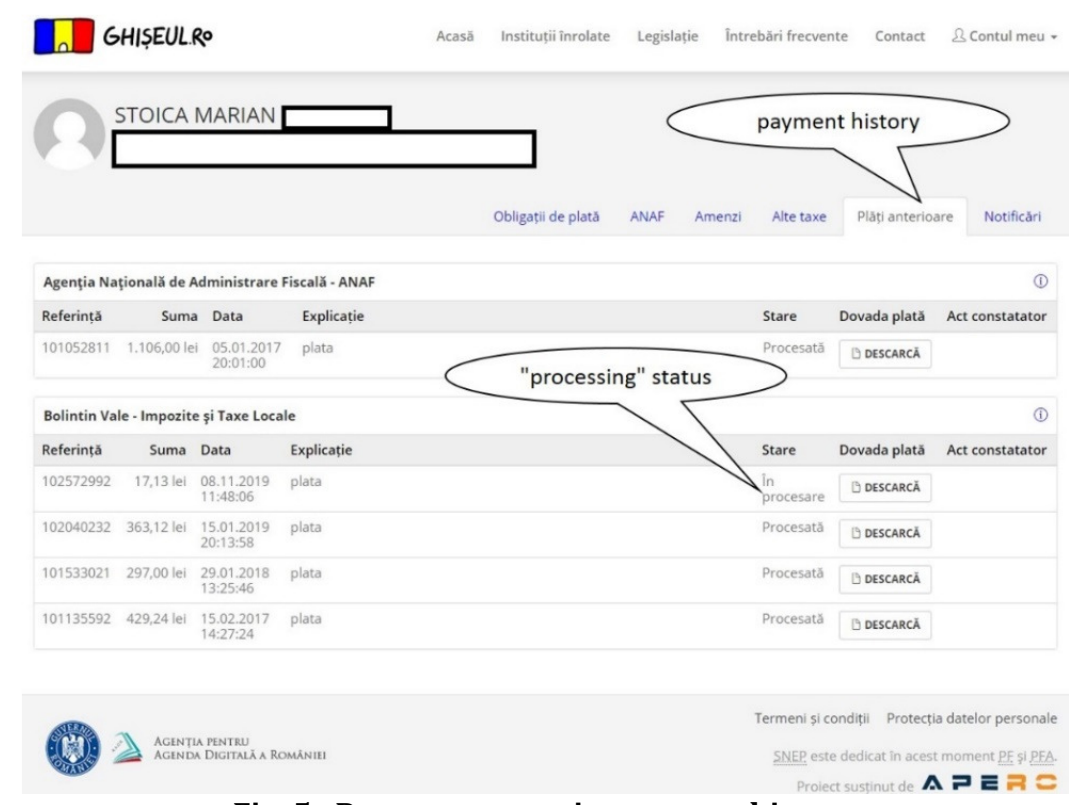

Fig. 5: Payment status in payment history

SNEP currently has 480568 active users, representing $5.6 \%$ of occupied population in Romania in the beginning of 2019 (8.588 mil. persons) or $7.41 \%$ of total employees in Romania (6.479 mil. persons). It may not be a huge number of active users, but it certainly is a good start.

The second solution covering the fiscal component of e-government is the portal of the National Agency for Fiscal Administration - anaf.ro. It targets both physical and juridical persons, offering them a series of instruments for information and uploading specific fiscal declarations, according to Romanian fiscal code (figure 6).

The anaf.ro portal may be accessed after a previous enrollment in the private virtual space of the application using a name and a password, followed by a second level of authentication using a security code valid for 5 minutes. The security code consists of six digits and is delivered via electronic mail immediately after entering the private virtual space.

Social-Economic Dimension of EGovernment - Involvement of Citizens and Business Environment
While electronic government is implemented top-down; from state to citizens, electronic democracy works bottom-up; from citizens to state. This comes from the positive impact the ICT has over the people, uniting common views on concrete issues. The state must consider these things when it wants to tackle local problems or when discussing new law projects. Also, from the citizens' opinions, the state will only gain its credibility and will be able to convince people to be more responsible and more involved in the community's affairs. This requires a certain status of the citizen regarding the actual involvement process, leading to the notion of active citizen. To achieve this status (as opposed to passive citizen), the state must follow a series of critical steps for its citizens:

- Continuous information about the citizens;

- $\quad$ Citizen representation;

- Encouraging the citizen to vote;

- Consulting the community for certain cases involving both local and central administration;

- Involving the citizen.

On the other side, the relation between government and the business environment (G2B) encompasses all actions between 
public and private environments. Just like the relation between government and citizens, the relation between companies and the government must be first and foremost transparent. The state must have an online platform to publish auctions of all state entities. This platform must be public, so anybody can access it. Such platform can reduce the number of fake auctions and every company can participate in auctions in its field of activity. Thus, the state spending will diminish and the state will benefit from increased trust from the private environment.

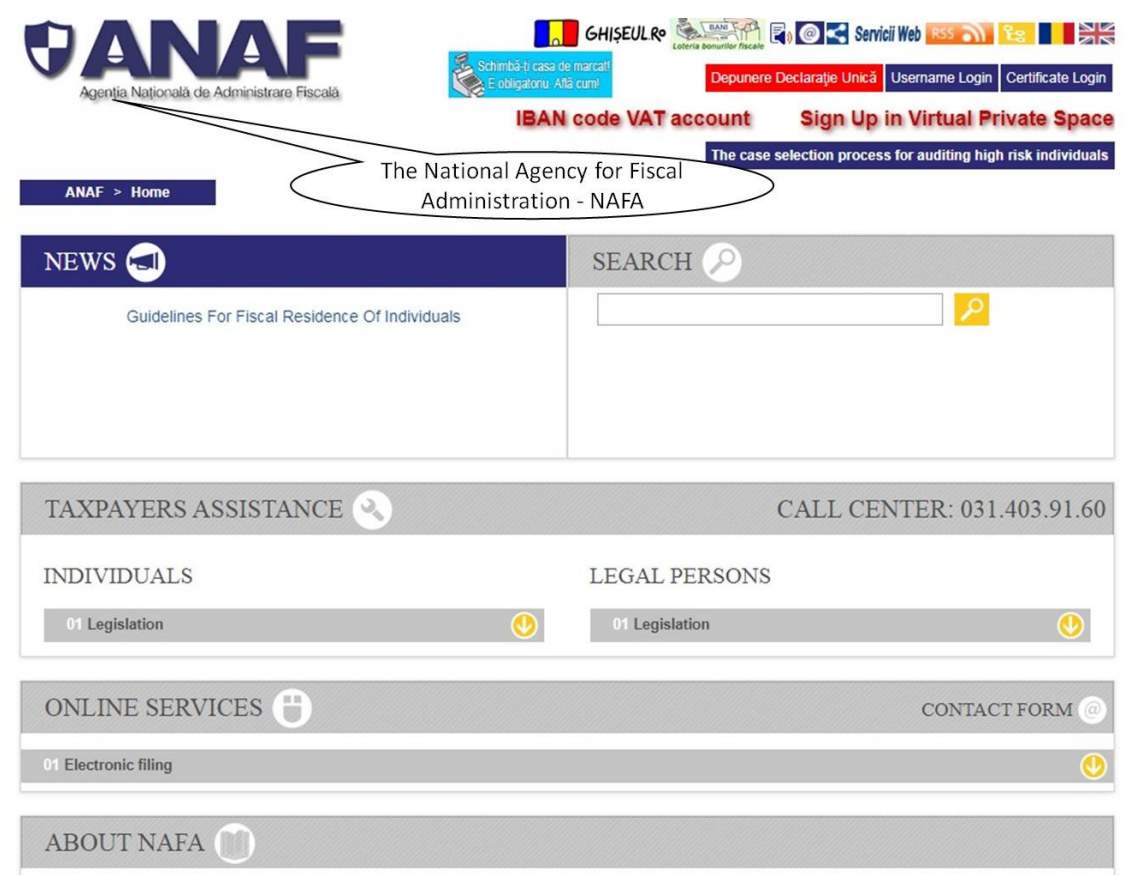

Fig. 6: National Agency for Fiscal Administration - NAFA portal

Romania has an electronic public procuring system, known as SEAP (figure 7), which includes a platform for publishing documentation for awarding public procuring procedures. Even more, since April 2nd, 2018, a new version of SEAP is available, after being developed under the project Collaborative information system for a performant environment for public procurement - SICAP, according to SEAP
(2019). It offers public authorities the necessary instruments for a complete cycle of public procurement, regardless the nature of the procurement procedure; open auctions, offer analyses, direct acquisition, frame contracts, etc. The system also targets economic agents, both domestic and foreign, that wish to participate in Romanian state public procurement procedures. 


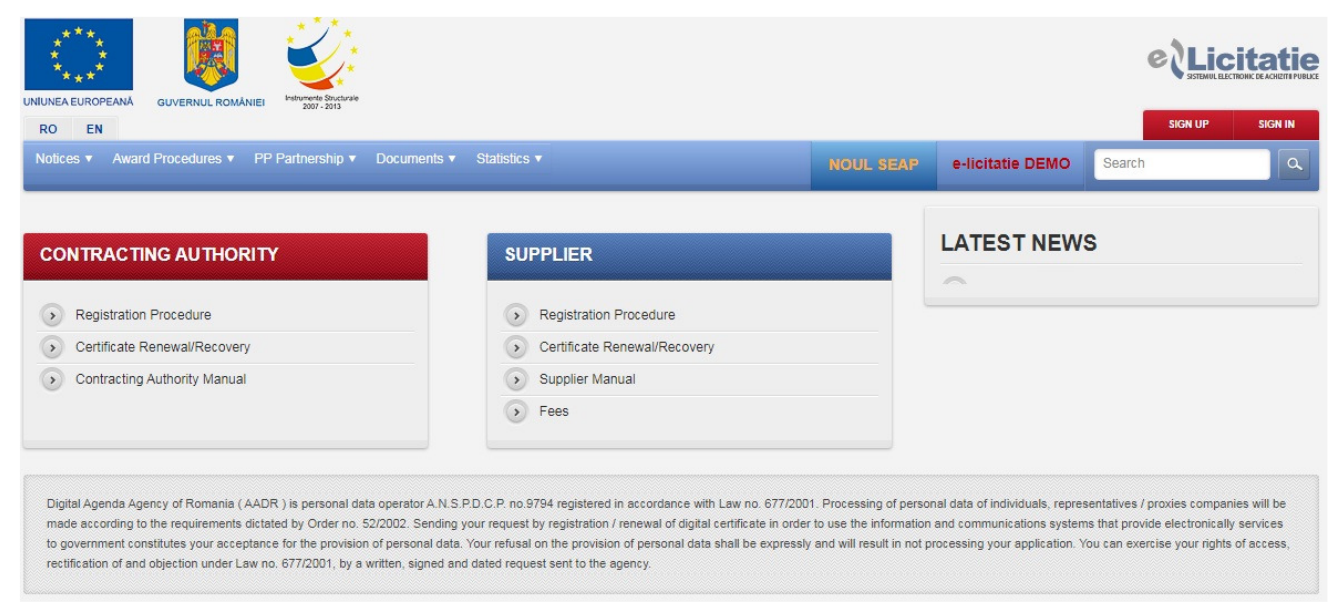

Fig. 7: Electronic public procurement system

A complete cycle of public procurement involves, in Romanian system, tracking and assisting the procedures from the initial phase of publishing awarding documentations, to the end of the procedure, and also tracking the implementation of the contracts and online payments. The system also uses electronic signature systems, for both the contracting authorities and the economic agents.

Electronic government also means streamlining the procedures involving the economic agents. First, the state must provide online information regarding the establishment of a company, aiming to perform online as many steps of the process as possible. Also, it must provide the possibility for the economic agents to perform most payments online. Romania has a state agency called Oficiul Național al Registrului Comerțului (National Trade Registry Office - NTRO) which provides juridical persons with online instruments for various business operations (issuing of documents, resolutions, statistics, establishing procedures etc., according to ONRC (2019).

The relation between the state and its employees, from the perspective of electronic government (G2E) aims to streamline state structure personnel activity. For example, the state must provide informational systems for its institutions that help employees store frequently used data. Thus, employees should be able to access online electronic archives, without searching in physical archives, reducing the delays in processing tasks. Also, though its e-government instruments, the state must provide the employees with informational systems that help register requests from citizens, with the possibility to approve them in the system. The workflow would be observed and the processing time will be reduced. In fact, the state must have a CRM (Customer Relationship Management) system, like private entities do.

Relations between government institutions (G2G) cover the communication between various state entities required to solve citizen issues. Through electronic government, communications between state institutions must take place mostly through global internet or private electronic networks. In most cases, information can be sent from one institution to another in an electronic form, without physical support. Using the network is a lot faster and also reduces costs. To achieve this, the various informational systems of the institutions must be interconnected. It involves standardization of communications, integration of infrastructures and interoperability of applications. Modern technologies provide support for other technologies. Problems arise only when attempting to connect technologies from separate generations. Also, there is a possibility that two institutions have incompatible technologies, or interconnecting them involves high costs. Any attempt to interconnect two 
institutions must take these aspects into account.

\section{Citizen Security In E-Government Context}

Developing e-government, which is based on internet, faces critical security hurdles due to the complexity and vulnerability of the network. Generally, security risks facing electronic government include the following aspects:

- Intercepting information - users or intruders (individuals or intelligent agents with malicious intents) capture or steal e-information from governments or other users.

- Altering of information - internet attackers manipulate, insert or delete original data through various techniques and send them to a destination affecting data integrity.

- Suspension of services - complete invalidation of the network system or server system during some periods. This arises from hacker or virus attacks and destruction of devices.

- Stealing system resources - in network systems environments, stealing system resources is a common problem.

In order to ensure citizen security, there is a need for procedures to register, store, process and use data. These procedures must be observed by both state institutions and private agents that need certain data. If anybody can use people's data, they can try to get undeserved benefits from these people. There are numerous cases where attackers use victims' personal data to impersonate them, blackmail them or other illegal activities. Prevention and fighting back require a good legislation for data protection, targeting both state institutions and private entities. Such legislation must specify what an entity may ask from a person, if it is allowed to store that data, if it is allowed to further transmit it or use it at a later time etc. Romania has Law 129 of June $15^{\text {th }}, 2018$, that modifies and completes Law $102 / 2005$ regarding establishing organization and functioning of National Supervisory Authority for Personal Data Processing and abrogation of Law $677 / 2001$ for protection of persons regarding processing their personal data and their free circulation, according to Lege 129 (2018). The problem with such law is that it is not observed. That is why substantial penalties must be imposed on those that do not observe it. Also, each entity that collects and processes personal data must be registered and must clearly specify what data it uses and towards which goal.

For the online environment, the same legislation must be applied, because many sites work with personal data. Also, there is a need for legislation regarding storing the history of a user's activity on a site, cookie policy and password storage, because these are important aspects for citizen security. The state must specify how long a site may store a user's history and what a site may do with a user's cookies, because otherwise it is very easy to undermine a user's security by attacking a site that stores lots of information about a user.

\section{Conclusions}

The problem of electronic government for state institutions is not necessarily in adopting technology in their activity, but more in convincing the people that this is the right way. People do not often embrace change and are reluctant or refractory to changes brought in. Also, it is possible that people do not know how to use new applications. That is why more training sessions for civil servants are needed. A huge improvement that can be brought to electronic government is reduction of bureaucracy. It can be done only if connections between institutions and departments are made and civil servants learn how to use them.

In most countries, the implementation of electronic government has also led to the creation of laws that force institutions to use electronic services. For example, in some countries, including Romania, some institutions are required to answer e-mail requests in a fixed interval. This has led to 
increased number of requests received by the institutions. Electronic government also comes with new procedures that will require a juridical foundation to be used. This technology, an upgrading and a digitization movement for the administrative system, will lead to the reorganization of some public institutions. At the beginning of the implementation of electronic government, increased human resources will be needed, but a successful implementation will lead in the end to a revolution on the state system, which will require less resources. One possible way to avoid unemployment of civil servants is to increase the number of services they provide to the citizens. Another way is to reallocate the personnel. Both ways scare people and they are inclined to reject the new solutions.

Electronic government must be centered on citizens and this involves storing a lot of information about them. This may lead to violation of privacy or accessing private data, which is unconceivable for a modern state. This kind of problems must be tackled through a well-built legislative framework regarding personal data, procedures that prevent civil servants from stealing date from state systems and also the use of secure information systems, without system vulnerabilities and backdoors that might be used by malicious agents. The state also must take the initiative in combating cybernetic criminality and ensuring citizen security.

Electronic government is a concept that involves digitizing interactions between state institutions and the citizens. This requires the implementation of complex solutions that must fulfill criteria regarding scalability, interoperability and security. The last aspect is critical for the citizen security, because the state must ensure citizens' personal data confidentiality. Since the state processes a lot of personal data, it must guarantee the security of these data for the citizens. If there are too many breaches in public institution informational systems, the people will want to return to old data storage methods because they will have more trust in the physical documents they have.
Creation of information systems for the state activity must not be entrusted to a single company or institution, since this will lead to a limitation of applications. The design process must mandatory take into account the use of modern technologies that facilitate communication with other informational systems, and a simple interface for users. Electronic government faces hurdles all over the world, related to laws, administrative institutions, technological factors and people. Even if switching to electronic government will take time, it will unavoidably happen. It is important to do it correctly without useless consumption of resources.

\section{References}

- Ana, A. (2018)," Ce înseamnă eguvernarea?", [Online], [Retrieved June 17, 2019], https://smartcityblog.ro/ceinseamna-e-guvernarea/

- Dumitrache, A. (2019), Mai multă guvernare electronică în România? Poate din 2019 și după studii și analize estimate la 11,2 milioane de lei, [Online], [Retrieved September 29, 2019],

https://www.profit.ro/stiri/social/mai -multa-guvernare-electronica-inromania-poate-din-2019-si-dupastudii-si-analize-estimate-la-11-2$\underline{\text { milioane-de-lei-16918627 }}$

- E-Guvernare (2019), Sistemul Electronic Național. E-Guvernare. [Online], [Retrieved October 21, 2019], http://www.e-guvernare.ro/

- Ghilic-Micu, B. (2002) 'Guvernarea electronică', Informatica Economică Journal, issue no. 1(21)/2002, pp. 18-22

- Ghilic-Micu B. and Stoica M. (2002), eActivităţile în societatea informaţională, Ed. Economică, Bucharest, ISBN 973-590-589-2

- $\quad$ Lege 129 (2018), Legea nr. 129 din 15 iunie 2018 pentru modificarea şi completarea Legii nr. 102/2005 privind înfiinţarea, organizarea şi funcţionarea 
Autorităţii Naţionale de Supraveghere a Prelucrării Datelor cu Caracter Personal, precum şi pentru abrogarea Legii nr. 677/2001 pentru protecția persoanelor cu privire la prelucrarea datelor cu caracter personal şi libera circulaţie a acestor date. [Online], [Retrieved October 25, 2019], https://www.dataprotection.ro/servle t/ViewDocument?id=1502

- ONRC (2019), Oficiul Național al Registrului Comerțului, site oficial, [Online], [Retrieved May 18, 2019], https://www.onrc.ro/index.php/ro/
- $\quad$ SEAP (2019), Sistemul Electronic de Achiziții Publice, [Online], [Retrieved October 25, 2019], http://sicap-prod.elicitatii.ro/pub

- Worldbank Report (2018), „Ukraine eGovernment Assessment", Published by Worldbank Group. [Online], [Retrieved October 12, 2018], https://openknowledge.worldbank.org /handle/10986/31052 